\title{
Copper sulfate toxicity to two isolates of Ichthyophthirius multifiliis relative to alkalinity
}

\author{
David L. Straus ${ }^{1, *}$, M. Mozammal Hossain ${ }^{2}$, Theodore G. Clark ${ }^{2}$ \\ ${ }^{1}$ US Department of Agriculture, Agricultural Research Service, Harry K. Dupree Stuttgart National Aquaculture Research \\ Center, 2955 Highway 130 E, PO Box 150, Stuttgart, Arkansas 72160, USA \\ ${ }^{2}$ Department of Microbiology and Immunology, College of Veterinary Medicine, Cornell University, \\ C5 181 Veterinary Medical Center, C5 163, Ithaca, New York 14853, USA
}

\begin{abstract}
Theronts from 2 different strains of Ichthyophthirius multifiliis (AR1 and AR5) were exposed to copper sulfate $\left(\mathrm{CuSO}_{4}\right)$ in waters of different total alkalinities and observed for $4 \mathrm{~h}$ to determine relative toxicity and kinetics of parasite mortality. Consistent with the known solubility properties of the metal, Cu was significantly more toxic to cells maintained under low (48 $\mathrm{mg} \mathrm{l}^{-1}$ ) compared with high (243 $\mathrm{mg} \mathrm{l}^{-1}$ ) total alkalinity conditions. This was reflected in both the median lethal concentration $\left(\mathrm{LC}_{50}\right)$ values and rates of mortality for both parasite strains; strain differences were also observed. The AR1 strain was significantly more resistant to copper toxicity than the AR5 strain in both high and low alkalinity waters. In general, these strain differences were more evident under conditions of low stress (i.e. low $\mathrm{CuSO}_{4}$ concentration and high alkalinity), and suggest that genetic factors are overridden under high stress conditions. The present study establishes a role for alkalinity in the effectiveness of $\mathrm{CuSO}_{4}$ treatment of ichthyophthiriasis and reveals differences in the susceptibility of parasite populations that are clearly important for control programs.
\end{abstract}

KEY WORDS: Strain differences · Ichthyophthirius multifiliis · Copper toxicity

\section{INTRODUCTION}

The protozoan parasite Ichthyophthirius multifiliis has significant impact on commercial aquaculture worldwide (Matthews 2005). The life cycle of $I$. multifiliis is well documented. Free-swimming infective theronts invade the skin and gill epithelia and rapidly transform into trophonts that feed on host tissue. Over the course of several days, trophonts grow and become visible to the naked eye as white spots. Mature trophonts then leave the host, attach to a solid surface and secrete a gelatinous capsule in which they encyst. Encysted tomonts finally divide to form 100 to 1000 infective theronts to complete the life cycle (Beckert \& Allison 1964, Nigrelli et al. 1976, Schäperclaus 1991, Lom \& Dyková 1992). Killing the infective theront or the detached trophont with various anti-protozoal drugs can stop the reproductive cycle and prevent spread of the disease to other fish (Tucker \& Robinson 1990, Schäperclaus 1991).

Copper sulfate $\left(\mathrm{CuSO}_{4}\right)$ is used extensively in aquaculture as a U.S. Environmental Protection Agencyapproved algicide. It is also used as a therapeutant for protozoan parasites including Ichthyophthirius multifiliis in commercial and recreational fish ponds. Although $\mathrm{CuSO}_{4}$ is not approved by the U.S. Food \& Drug Administration (FDA) for use on food fish, regulatory action by the FDA awaits ongoing research.

The toxicity (or efficacy as a control measure) of $\mathrm{CuSO}_{4}$ to an organism is strongly influenced by water chemistry and is diminished as the total alkalinity and total hardness of waters increase. The form of copper most toxic to fish, and presumably also to algae and protozoans, is thought to be $\mathrm{Cu}^{++}$(Straus \& Tucker 1993). At low alkalinities, copper remains in solution for long periods and forms relatively insoluble com- 
pounds at high alkalinities (Chakoumakos et al. 1979, Laurén \& McDonald 1986). To account for this reduced toxicity or efficacy, the current practice for therapeutic use of $\mathrm{CuSO}_{4}$ in culture ponds is to increase application rates in direct proportion to the total alkalinity of the water (MacMillan 1985, Tucker \& Robinson 1990).

It has become clear over the past decade that natural isolates of Ichthyophthirius multifiliis can be distinguished based on a number of criteria, most notably, the expression of surface immobilization antigens or i-antigens (Clark \& Forney 2003). These antigens vary among natural isolates, and either monoclonal antibodies or reference polyclonal antisera that bind specific i-antigens can be used to define serotypes in simple immobilization assays (Dickerson et al. 1993, Swennes et al. 2006). Previous work has shown that serotype D strains are the most common in nature and express an abundant $55 \mathrm{kDa}$ i-antigen on their surface (Wang et al. 2002). At least 5 additional serotypes of I. multifiliis have been identified based on antibodyspecific immobilization (Wang et al. 2002, Swennes et al. 2007, Xu et al. 2006), including serotype $F$, for which reference antisera have been produced (T.G.C. \& D.L.S. unpubl. data); the single representative of this serotype (isolate AR1) was obtained from an outbreak in central Arkansas in 2005. A report by Swennes et al. (2007) has suggested that different strains of I. multifiliis vary with respect to virulence, and it would be reasonable to assume they differ in other phenotypic character traits as well.

Previous research has investigated the effectiveness of $\mathrm{CuSO}_{4}$ in controlling Ichthyophthirius multifiliis in several species of fish (Ling et al. 1993, Straus 1993, Schlenk et al. 1998, Tieman \& Goodwin 2001, Goodwin \& Straus 2006, Straus 2008, Rowland et al. 2009). The objective of the present study was to evaluate the acute toxicity of $\mathrm{CuSO}_{4}$ to free-swimming theronts of I. multifiliis in waters having different total alkalinities with the same total hardness. The present study shows that alkalinity had a clear effect on copper toxicity while different parasite strains were differentially sensitive to copper treatment.

\section{MATERIALS AND METHODS}

Parasite culture. The 2 isolates of Ichthyophthirius multifiliis, AR1 and AR5, were maintained in separate aquaria by serial infection of fingerling channel catfish Ictalurus punctatus ( 75 to $100 \mathrm{~g}$ ). The AR1 isolate came from infected sunshine bass (o Morone chrysops $\times 0^{7}$ M. saxatilis) and was defined as serotype $F$ using reference antibodies against existing strains. The AR5 isolate belongs to the previously identified serotype D (Dickerson et al. 1993) and was isolated from infected channel catfish from central Arkansas. AR1 and AR5 isolates were maintained as laboratory cultures for 14 and $7 \mathrm{mo}$, respectively, at the time experiments were carried out. Fish were held at $25^{\circ} \mathrm{C}$ in static $38 \mathrm{l}$ aquaria filled with $30 \mathrm{l}$ of well water (alkalinity $=212 \mathrm{mg} \mathrm{l}^{-1}$, hardness $=103 \mathrm{mg} \mathrm{l}^{-1}, \mathrm{pH}=8.7$ ); aquaria were fitted with outside biological filters containing pea gravel.

Preparation of theronts. Fish with mature trophonts were pithed and placed in a beaker containing clean well water. Trophonts were allowed to dislodge from the fish ( 3 to $4 \mathrm{~h}$ ) and the fish were removed. Trophonts were allowed to adhere to the beaker for $1 \mathrm{~h}$ and were gently rinsed to remove organic matter. Approximately half of the trophonts were rinsed into a beaker with a gentle stream of $48 \mathrm{mg} \mathrm{l}^{-1}$ alkalinity water until the beaker was filled to $100 \mathrm{ml}$. The remaining trophonts were likewise rinsed with a gentle stream of $243 \mathrm{mg} \mathrm{l}^{-1}$ alkalinity water into a beaker until the beaker was filled to $100 \mathrm{ml}$. Trophonts were then incubated at room temperature for $18 \mathrm{~h}( \pm 1 \mathrm{~h})$ to allow for mitotic division. After incubation, theront development was similar for both isolates. Previous observations in our labs have shown that immature trophonts are spherical and require more time to mature to the typical oblong shape; after the $18 \mathrm{~h}$ incubations, the majority of theronts from a single tomont are typically $3 \mathrm{~h}$ old. Theront concentrations were estimated by pipetting $5 \mu \mathrm{l}$ droplets of the theront suspension onto a glass slide and counting the organisms at $40 \times$ magnification; the mean count in 10 droplets was extrapolated to determine the final concentrations in a suspension (Schlenk et al. 1998).

Serotype determination. Immobilization assays were carried out to determine the respective i-antigen serotypes of the AR1 and AR5 isolates (Dickerson et al. 1993). AR5 was identified as serotype D using monoclonal antibody G3-61 (Lin et al. 1996). AR1 was not immobilized by any of the currently available monoclonal antibodies (MAbs) or reference antisera and was deemed to be a new variant, which we designated as serotype F. Reference antisera were therefore prepared against the AR1 strain in channel catfish using clonally derived parasites. Fish (1 kg channel catfish) were injected intraperitoneally with 15000 live theronts on 3 separate occasions at $21 \mathrm{~d}$ intervals. Sera from 3 individual fish were pooled and heatinactivated at $56^{\circ} \mathrm{C}$ for $30 \mathrm{~min}$ prior to storage at $-80^{\circ} \mathrm{C}$. The pooled antiserum was found to immobilize AR1 theronts to dilutions as high as 1:1280 and was specific for the AR1 strain. For immobilization assays, antisera against serotype F, or MAb G3-61 (specific for serotype D), were serially diluted in microtiter plates containing $50 \%$ phosphate-buffered saline in carbon-filtered tap water; 500 theronts were added to each well, and their motility was microscopically observed after 30 to 
60 min under low magnification. Cultures were considered to be composed of only 1 serotype if all theronts were completely immobilized by specific antibodies.

Test waters. Total alkalinity and total hardness (as $\mathrm{CaCO}_{3}$ ) were measured by titration method (APHA et al. 2005). $\mathrm{pH}$ was measured with a Thermo Orion Model 720A bench top meter (Thermo Electron). Dechlorinated tap water (48 $\mathrm{mg} \mathrm{l}^{-1}$ alkalinity, $\mathrm{pH} 7.1$ ) was adjusted with sodium bicarbonate to increase alkalinity 5-fold (243 $\mathrm{mg} \mathrm{l}^{-1}$ alkalinity, $\mathrm{pH}$ 8.1). Hardness was $24 \mathrm{mg} \mathrm{l}^{-1}$ in both waters.

Toxicity assays. In vitro bioassays were conducted on theronts of each strain following the method of Straus \& Griffin (2001). Approximately 200 theronts were placed in each well of a 96-well microtiter plate (Falcon 3912, non-tissue culture treated, Becton Dickinson Labware) and exposed at $25^{\circ} \mathrm{C}$ to nominal concentrations of copper (as $\mathrm{CuSO}_{4} ; 0.025,0.05,0.075$, 0.10 , and $0.125 \mathrm{mg} \mathrm{l}^{-1}$ ). All treatments were conducted in triplicate $(\mathrm{N}=3)$ and unexposed controls were included with each replicate. The $\mathrm{CuSO}_{4} \cdot 5 \mathrm{H}_{2} \mathrm{O}(25.4 \%$ $\mathrm{Cu}$ ) used in this experiment was purchased from Sigma Chemical. Acute toxicity was determined by microscopic examination of each well at 15, 30, 45, 60, 120,180 , and 240 min after treatment. Mortality of the ciliates was defined as the lack of movement.

Statistical analyses. Nominal copper concentrations and percent theront mortality were used to calculate the median lethal concentration $\left(\mathrm{LC}_{50}\right)$ values for each replicate using the PROBIT procedure of the SAS System for Windows (version 9.1.3, SAS Institute). Subsequently, differences in $\mathrm{LC}_{50}$ values among treatments were analyzed using PROC MIXED to conduct a factorial mixed model analysis of variance in which strain, alkalinity, and time were defined as the fixed effects, and replication within strain $\times$ alkalinity was defined as the random effect with compound symmetric variance-covariance structure. When significant differences were found, least-squares means were separated by the least significant difference. Associated $95 \%$ CI were calculated to assess the biological importance of differences. Kaplan-Meier curves were generated to illustrate the mortality of the parasites during the bioassay. Using GraphPad Prism version 5.01 for Windows (GraphPad Software), survival analysis using a log-rank test was conducted to examine the survival differences among the curves. All treatment effects were considered significant at the $\mathrm{p}<0.05$ level.

\section{RESULTS AND DISCUSSION}

Isolates were maintained in culture water under different alkalinity, hardness, and $\mathrm{pH}$ levels than in the toxicity assays. Both strains were exposed to the same

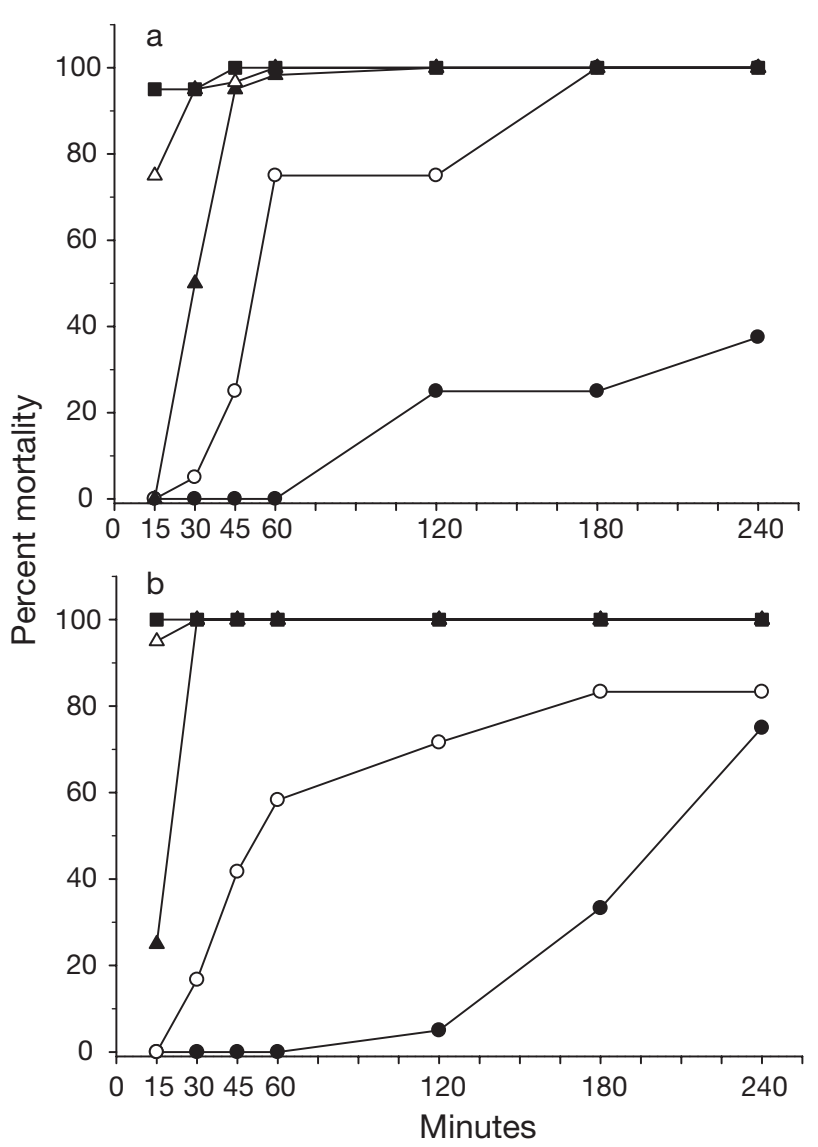

Fig. 1. Ichthyophthirius multifiliis. Percent mortality of strain (a) AR1 and (b) AR5 theronts exposed to copper in vitro $(\mathrm{N}=$ $3 ; \mathrm{N}=2$ for AR1 in $0.025 \mathrm{mg} \mathrm{l}^{-1} \mathrm{Cu}$ ) in dechlorinated tap water with $48 \mathrm{mg} \mathrm{l}^{-1}$ alkalinity. $\mathrm{Cu}$ concentrations were:

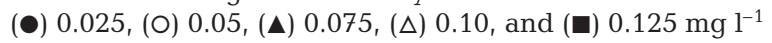

changes in water chemistries and this was not considered to have an impact on toxicity results. The trophonts were allowed to encyst, develop tomites, and release theronts in their respective test waters.

Kaplan-Meier survival curves were generated for 2 different isolates of Ichthyophthirius multifiliis in response to increasing copper concentrations in waters of low and high alkalinity from the raw data in Figs. 1 $\& 2$. Irrespective of strain, copper toxicity was more acute in low alkalinity water. This is illustrated in Fig. 3a, which plots the survival curves for the AR1 isolate at $0.075 \mathrm{mg} \mathrm{l}^{-1} \mathrm{Cu}$ in both waters. Under these conditions, the time required to kill $95 \%$ of parasites was $\sim 4$ times faster in water with 48 rather than $243 \mathrm{mg} \mathrm{l}^{-1}$ alkalinity (45 $\mathrm{min}$ vs. $180 \mathrm{~min}$, respectively). These data are consistent with solubility properties of copper and the current understanding of $\mathrm{CuSO}_{4}$ toxicity in other aquatic organisms such as fish. Teleosts are more sensitive to $\mathrm{CuSO}_{4}$ in low alkalinity and/or hardness waters (Chakoumakos et al. 1979, Laurén \& McDonald 


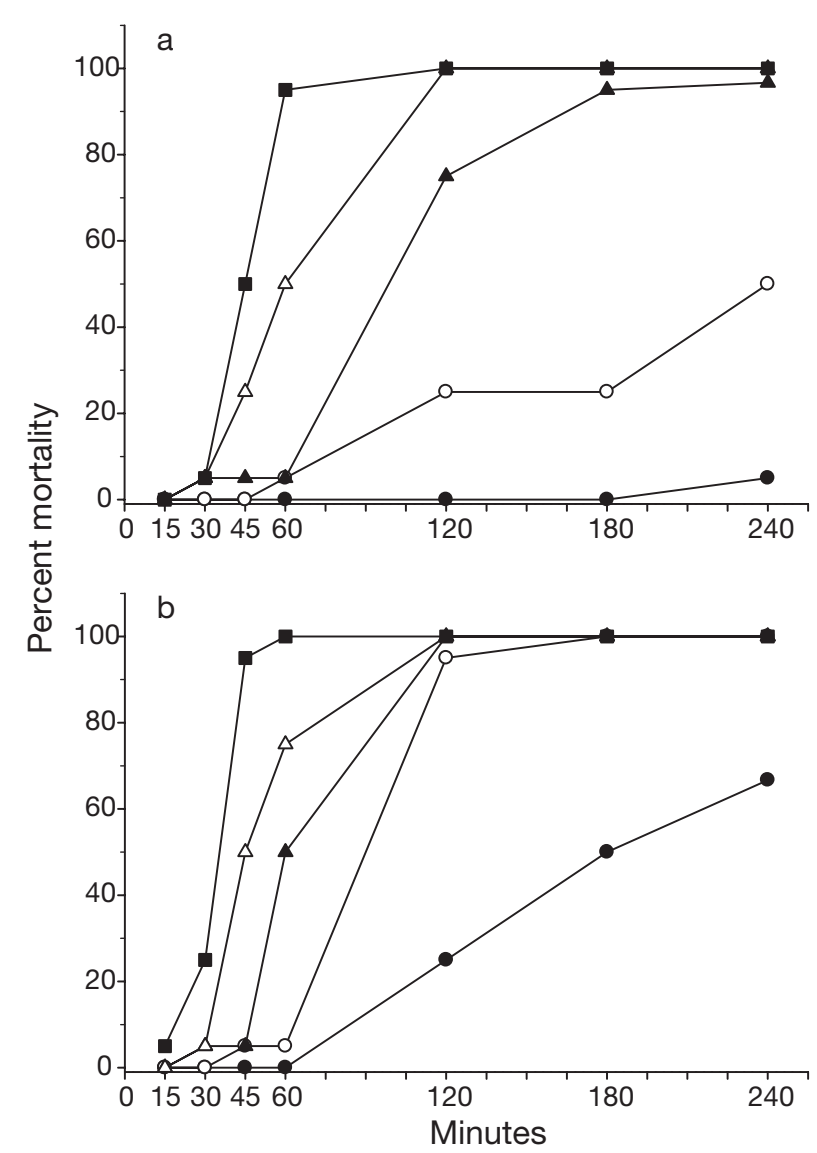

Fig. 2. Ichthyophthirius multifiliis. Percent mortality of strain (a) AR1 and (b) AR5 theronts exposed to copper in vitro ( $\mathrm{N}=$ 3) in dechlorinated tap water with $243 \mathrm{mg} \mathrm{l}^{-1}$ alkalinity.

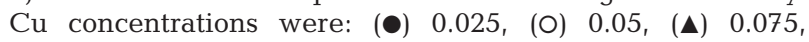
$(\Delta) 0.10$, and $(\square) 0.125 \mathrm{mg} \mathrm{l}^{-1}$

1986, Straus \& Tucker 1993), with toxicity being due primarily to osmoregulatory dysfunction (Hargreaves \& Tomasso 2004). This may be the case for I. multifiliis as well, although the precise mechanism of heavy metal action in protozoa remains to be determined.

Significant differences were seen between AR1 and AR5 strains in waters of both alkalinities when KaplanMeier survival curves for the 2 strains of Ichthyophthirius multifiliis were compared. In the $48 \mathrm{mg} \mathrm{l}^{-1}$ alkalinity water, significant differences were observed at concentrations of $0.075,0.10$, and $0.125 \mathrm{mg} \mathrm{l}^{-1} \mathrm{Cu}$ (Figs. 1a,b). In the higher alkalinity water $\left(243 \mathrm{mg} \mathrm{l}^{-1}\right)$, significant differences in Kaplan-Meier survival curves were found at all copper concentrations (Figs. 2a,b). Differences in copper sensitivities between strains are illustrated in Fig. 3b, which shows the survival curves of AR1 and AR5 strains at $0.075 \mathrm{mg} \mathrm{l}^{-1} \mathrm{Cu}$ in $243 \mathrm{mg} \mathrm{l}^{-1}$ alkalinity water. Half of the AR5 strain population was dead after $60 \mathrm{~min}$, while the entire population was unresponsive after $120 \mathrm{~min}$. By contrast, most of the
AR1 population was alive at $120 \mathrm{~min}$, and by the end of the bioassay, $5 \%$ still exhibited movement at this copper concentration.

When measured in terms of $\mathrm{LC}_{50}$ values (Table 1), significant differences between the 2 strains were evident at the 15 and $30 \mathrm{~min}$ time points in water of $48 \mathrm{mg}$ $\mathrm{l}^{-1}$ alkalinity. Differences were not significant at the 45 min time point and beyond, and data were not sufficient to calculate a valid $\mathrm{LC}_{50}$ value for the AR5 strain at $240 \mathrm{~min}$. Failure to obtain statistically significant differences at later time points (or a valid $\mathrm{LC}_{50}$ for the 240 min time point with AR5) was due to the high copper toxicity in low alkalinity water. Table 2 shows the $\mathrm{LC}_{50}$ values for both strains in $243 \mathrm{mg} \mathrm{l}^{-1}$ alkalinity water. In this case, statistically significant differences between AR1 and AR5 strains were evident at later time points $(45,60,120$, and $180 \mathrm{~min})$, but valid $\mathrm{LC}_{50}$ values could not be obtained at the earlier time points due to the absence of a strong effect at 15 and $30 \mathrm{~min}$. The $\mathrm{LC}_{50}$ values and statistical analyses provided in Tables $1 \& 2$ suggest that under high physiological

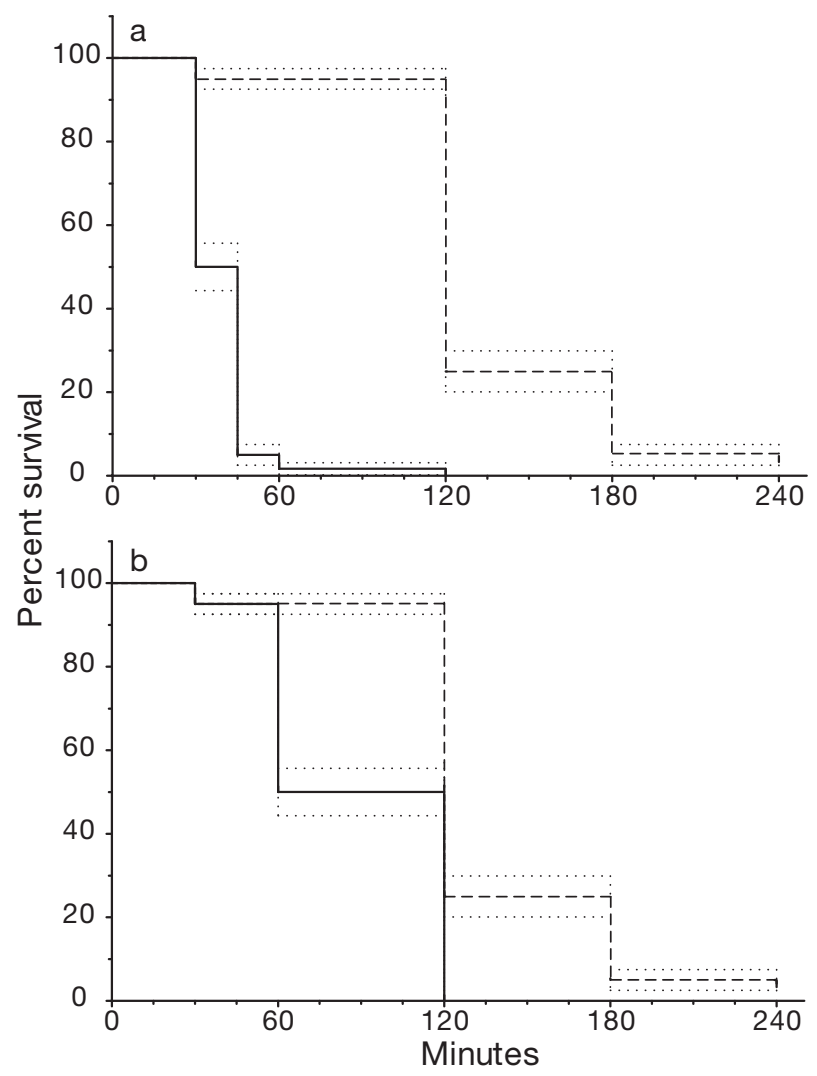

Fig. 3. Ichthyophthirius multifiliis. Kaplan-Meier survival curves. (a) AR1 strain at $0.075 \mathrm{mg} \mathrm{l}^{-1} \mathrm{Cu}$ in (solid line) $48 \mathrm{mg}$ $\mathrm{l}^{-1}$ and (dashed line) $243 \mathrm{mg} \mathrm{l}^{-1}$ alkalinity waters. Survival was significantly lower at $48 \mathrm{mg} \mathrm{l}^{-1}$ alkalinity. (b) AR1 (dashed line) and AR5 (solid line) strains at $0.075 \mathrm{mg} \mathrm{l}^{-1} \mathrm{Cu}$ in $243 \mathrm{mg}$ $\mathrm{l}^{-1}$ alkalinity waters. Survival of the AR1 strain was significantly greater. Dotted lines: $95 \%$ CI 
Table 1. Ichthyophthirius multifiliis. Median lethal concentration $\left(\mathrm{LC}_{50}\right)$ values $\left(\mathrm{mg} \mathrm{l}^{-1} \mathrm{Cu}\right)$ and $95 \%$ CI of copper to AR1 and AR5 strains in $48 \mathrm{mg} \mathrm{l}^{-1}$ alkalinity dechlorinated tap water over $4 \mathrm{~h}$. nd: Not determined (Cu concentrations were not appropriate to calculate $\mathrm{LC}_{50}$ values). ${ }^{*}$ : Significant difference (SAS MIXED procedure)

\begin{tabular}{|c|c|c|c|c|}
\hline Time (min) & AR1 strain $\mathrm{LC}_{50}$ value $(95 \% \mathrm{CI})$ & AR5 strain $\mathrm{LC}_{50}$ value $(95 \% \mathrm{CI})$ & Difference (95\% CI) & $\mathrm{p}$ \\
\hline 15 & $0.095(0.092,0.099)$ & $0.082(0.078,0.085)$ & $-0.014(-0.019,-0.009)$ & $<0.0001^{*}$ \\
\hline 30 & $0.074(0.071,0.078)$ & $0.055(0.051,0.059)$ & $-0.019(-0.024,-0.014)$ & $<0.0001^{*}$ \\
\hline 45 & $0.057(0.053,0.061)$ & $0.051(0.047,0.054)$ & $-0.006(-0.012,-0.001)$ & 0.0159 \\
\hline 60 & $0.047(0.043,0.050)$ & $0.049(0.046,0.053)$ & $0.003(-0.003,0.008)$ & 0.3137 \\
\hline 120 & $0.039(0.035,0.042)$ & $0.041(0.037,0.044)$ & $0.002(-0.003,0.007)$ & 0.4535 \\
\hline 180 & $0.027(0.023,0.031)$ & $0.030(0.026,0.034)$ & $0.003(-0.003,0.009)$ & 0.2998 \\
\hline 240 & $0.026(0.022,0.031)$ & nd & nd & nd \\
\hline
\end{tabular}

Table 2. Ichthyophthirius multifiliis. Median lethal concentration $\left(\mathrm{LC}_{50}\right)$ values $\left(\mathrm{mg} \mathrm{l}^{-1} \mathrm{Cu}\right)$ and $95 \% \mathrm{CI}$ of copper to AR1 and AR5 strains in $243 \mathrm{mg} \mathrm{l}^{-1}$ alkalinity dechlorinated tap water over $4 \mathrm{~h}$. nd: Not determined (Cu concentrations were not appropriate to calculate $\mathrm{LC}_{50}$ values). ${ }^{*}$ : Significant difference (SAS MIXED procedure)

\begin{tabular}{|c|c|c|c|c|}
\hline Time (min) & AR1 strain $\mathrm{LC}_{50}$ value $(95 \% \mathrm{CI})$ & AR5 strain $\mathrm{LC}_{50}$ value $(95 \% \mathrm{CI})$ & Difference (95\% CI) & $\mathrm{p}$ \\
\hline 15 & nd & nd & nd & nd \\
\hline 30 & nd & nd & nd & nd \\
\hline 45 & $0.124(0.121,0.128)$ & $0.096(0.092,0.100)$ & $-0.028(-0.033,-0.023)$ & $<0.0001^{*}$ \\
\hline 60 & $0.096(0.092,0.100)$ & $0.077(0.074,0.081)$ & $-0.019(-0.024,-0.014)$ & $<0.0001^{*}$ \\
\hline 120 & $0.060(0.057,0.064)$ & $0.031(0.027,0.034)$ & $-0.030(-0.035,-0.025)$ & $<0.0001^{*}$ \\
\hline 180 & $0.056(0.053,0.060)$ & $0.025(0.021,0.029)$ & $-0.031(-0.036,-0.026)$ & $<0.0001^{*}$ \\
\hline 240 & $0.046(0.043,0.050)$ & nd & nd & nd \\
\hline
\end{tabular}

stress situations (low alkalinity/high toxicity) genetic factors are over-ridden, while under low physiological stress, strain differences become evident.

Total hardness is caused by a variety of dissolved polyvalent metallic ions, predominantly calcium and magnesium cations, although other cations (e.g. barium, iron, manganese, strontium, zinc) may also contribute (WHO 2003). Calcium and magnesium are the most common sources of water hardness reported in aquaculture conditions (Boyd \& Tucker 1998). Calcium carbonate $\left(\mathrm{CaCO}_{3}\right)$ hardness is a general term that indicates the total quantity of divalent salts present and does not specifically identify whether calcium, magnesium, and/or some other divalent salt is causing water hardness (Wurts \& Durborow 1992). Prevailing situations in areas where calcium or magnesium (approximately 27 and $7 \mathrm{mg} \mathrm{l}^{-1}$, respectively, in the present study) are not the dominant divalent cations can have different results than found in the present study.

Environmental pH and total alkalinity are major modulators of copper toxicity because they affect the total concentration and speciation of dissolved copper in solution (Boyd 1990). As pH increases over the range of 7 to 9, total dissolved copper and cupric ion concentrations decrease. As total alkalinity increases, a larger proportion of the total copper in solution is present as various carbonate complexes. In fish, hardness (specif- ically, calcium hardness) affects the toxicity of copper by modulating the fish's biological response to the metal; calcium ions may compete with cupric ions for cation binding or adsorption sites at the gill surface, resulting in decreased copper uptake by fish (Cusimano et al. 1986). A similar mechanism is suggested in the present study; however, other cations responsible for hardness may modulate copper toxicity more than calcium in different regions throughout the world.

The present study represents the first report demonstrating differences in sensitivity to $\mathrm{CuSO}_{4}$ between isolates of Ichthyophthirius multifiliis and complements a recent report by Swennes et al. (2006) that describes virulence differences between I. multifiliis serotypes. The differences in copper toxicity described here may explain anecdotal reports concerning the effectiveness of $\mathrm{CuSO}_{4}$ treatments in various localities and has obvious practical importance. While it is doubtful that copper sensitivity, virulence, and i-antigen serotype are phenotypically linked, such differences reflect the genetic potential of ciliate populations and warrant further study to develop effective treatment and/or vaccination regimes that are beneficial to the aquaculture industry as a whole.

Acknowledgements. S. J. Malone maintained the Ich culture and theront bioassays. Statistics were handled by C. R. Boyle (College of Veterinary Medicine, Mississippi State Univer- 
sity); her input was indispensable! J. A. Steeby, A. M. Darwish, and S. D. Rawles provided critical reviews of the manuscript. Studies were conducted in accordance with institutional, national, and international guidelines concerning the use of animals in research. This research was supported in part by the Cornell University Agricultural Experiment Station Federal Formula Funds, Project No. NYC-433404, received from the Cooperative State Research, Education and Extension Service, U.S. Department of Agriculture. Any opinions, findings, conclusions, or recommendations expressed in this publication are those of the authors and do not necessarily reflect the view of the U.S. Department of Agriculture. Mention of trade names or commercial products in this article is solely for the purpose of providing specific information and does not imply recommendation or endorsement by the U.S. Department of Agriculture.

\section{LITERATURE CITED}

APHA (American Public Health Association), American Water Works Association, Water Pollution Control Federation (2005) Standard methods for the examination of water and wastewater, 21st edn. Washington, DC, available at www.standardmethods.org

Beckert H, Allison R (1964) Some host responses of white catfish to Ichthyophthirius multifiliis, Fouquet. Proceedings of the Southeastern Association of Game and Fish Commissioners 18:438-441

Boyd CE (1990) Water quality in ponds for aquaculture. Alabama Agricultural Experiment Station, Auburn University

Boyd CE, Tucker CS (1998) Pond aquaculture water quality management. Kluwer Academic Publishers, Norwell, MA

Chakoumakos C, Russo RC, Thurston RV (1979) Toxicity of copper to cutthroat trout (Salmo clarki) under different conditions of alkalinity, $\mathrm{pH}$, and hardness. Environ Sci Technol 13:213-219

Clark TG, Forney JD (2003) Free-living and parasitic ciliates. In: Craig AG, Scherf A (eds) Antigenic variation. Academic Press, London, p 375-402

Cusimano RF, Brakke DF, Chapman GA (1986) Effects of pH on the toxicities of cadmium, copper, and zinc to steelhead trout (Salmo gairdneri). Can J Fish Aquat Sci 43:1497-1503

> Dickerson HW, Clark TG, Leff AA (1993) Serotypic variation among isolates of Ichthyophthirius multifiliis based on immobilization. J Eukaryot Microbiol 40:816-820

$>$ Goodwin AE, Straus DL (2006) Solid and liquid formulations of copper sulfate: efficacy at high and low alkalinities. North Am J Aquacult 68:359-363

Hargreaves JA, Tomasso JR (2004) Environmental biology. In: Tucker CS, Hargreaves JA (eds) Biology and culture of channel catfish. Developments in aquaculture and fisheries science series, Vol 34. Elsevier, Amsterdam, p 36-68

Laurén DJ, McDonald DG (1986) Influence of water hardness, $\mathrm{pH}$, and alkalinity on the mechanisms of copper toxicity in juvenile rainbow trout, Salmo gairdneri. Can J Fish Aquat Sci 43:1488-1496

Lin TL, Clark TG, Dickerson HW (1996) Passive immunization of channel catfish (Ictalurus punctatus) against the ciliated protozoan parasite Ichthyophthirius multifiliis by use of murine monoclonal antibodies. Infect Immun 64: 4085-4090

Ling KH, Sin YM, Lam TJ (1993) Effect of copper sulphate on ichthyophthiriasis (white spot disease) in goldfish (Carassius auratus). Aquaculture 118:23-35

Lom J, Dyková I (1992) Ciliates (Phylum Ciliophora Doflein,
1901). In: Protozoan parasites of fishes. Developments in aquaculture and fisheries science series, Vol 26. Elsevier, Amsterdam, p 237-288

MacMillan JR (1985) Infectious diseases. In: Tucker CS (ed) Channel catfish culture. Elsevier, Amsterdam, p 405-496

Matthews RA (2005) Ichthyophthirius multifiliis Fouquet and ichthyophthiriosis in freshwater teleosts. Adv Parasitol 59: 159-241

Nigrelli RF, Pokorny KS, Ruggieri GD (1976) Notes on Ichthyophthirius multifiliis, a ciliate parasitic on freshwater fishes, with some remarks on possible physiological races and species. Trans Am Microsc Soc 95:607-613

Rowland SJ, Mifsud C, Nixon M, Read P, Landos M (2009) Use of formalin and copper to control ichthyophthiriosis in the Australian freshwater fish silver perch (Bidyanus bidyanus Mitchell). Aquacult Res 40:44-54

Schäperclaus W (1991) Diseases caused by ciliates. In: Schäperclaus W, Kulow H, Schreckenbach K (eds) Fish diseases. US Department of the Interior and National Science Foundation, Washington, DC. Amerind Publishing, New Delhi, p 702-725

Schlenk D, Gollon JL, Griffin BR (1998) Efficacy of copper sulfate in the treatment of ichthyophthiriasis in channel catfish. J Aquat Anim Health 10:390-396

> Straus DL (1993) Prevention of Ichthyophthirius multifiliis infestation in channel catfish fingerlings by copper sulfate treatment. J Aquat Anim Health 5:152-154

Straus DL (2008) Comparison of copper sulfate concentrations to control ichthyophthiriasis in fingerling channel catfish. J Appl Aquacult 20:272-284

Straus DL, Griffin BR (2001) Prevention of an initial infestation of Ichthyophthirius multifiliis in channel catfish and blue tilapia by potassium permanganate treatment. North Am J Aquacult 63:11-16

Straus DL, Tucker CS (1993) Acute toxicity of copper sulfate and chelated copper to channel catfish Ictalurus punctatus. J World Aquacult Soc 24:390-395

> Swennes AG, Noe JG, Findly RC, Dickerson HW (2006) Differences in virulence between two serotypes of Ichthyophthirius multifiliis. Dis Aquat Org 69:227-232

> Swennes AG, Findly RC, Dickerson HW (2007) Cross-immunity and antibody responses to different immobilisation serotypes of Ichthyophthirius multifiliis. Fish Shellfish Immunol 22:589-597

> Tieman DM, Goodwin AE (2001) Treatments for ich infestations in channel catfish evaluated under static and flowthrough water conditions. North Am J Aquacult 63: 293-299

Tucker CS, Robinson EH (1990) Channel catfish farming handbook. Van Nostrand Reinhold, New York

Wang X, Clark TG, Noe J, Dickerson HW (2002) Immunisation of channel catfish, Ictalurus punctatus, with Ichthyophthirius multifiliis immobilisation antigens elicits serotype-specific protection. Fish Shellfish Immunol 13: $337-350$

WHO (World Health Organization) (2003) Hardness in drinking-water. Background document for preparation of WHO Guidelines for drinking-water quality. World Health Organization, WHO/SDE/WSH/03.04/6, Geneva

Wurts WA, Durborow RM (1992) Interactions of pH, carbon dioxide, alkalinity and hardness in fish ponds. Southern Regional Aquaculture Center, SRAC Publication No. 464, Stoneville, MS

Xu DH, Klesius PH, Panangala VS (2006) Induced crossprotection in channel catfish, Ictalurus punctatus (Rafinesque), against different immobilization serotypes of Ichthyophthirius multifiliis. J Fish Dis 29:131-138 